\title{
Jerome and Augustine on wealth and poverty in Psalms 107-150
}

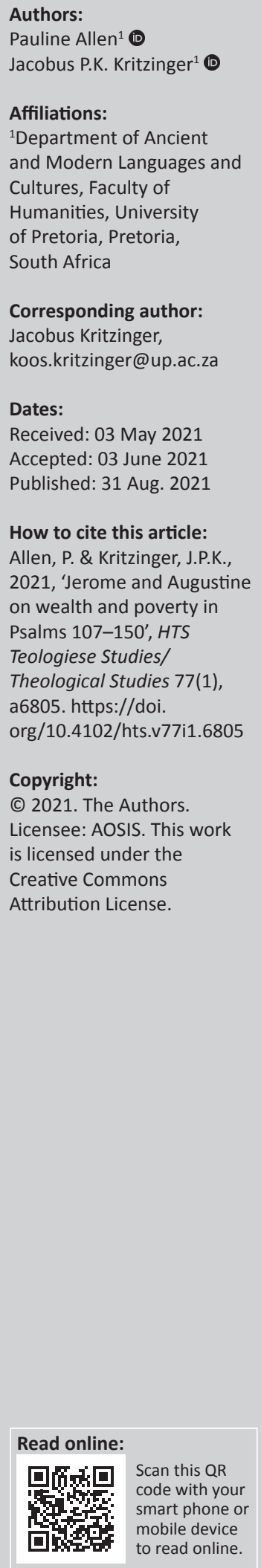

\section{Authors:}

Affiliations:

${ }^{1}$ Department of Ancient ( Humanities, University of Pretoria, Pretoria

Jacobus Kritzinger

Dates:

Accepted: 03 June 2021

How to cite this article:

Allen, P. \& Kritzinger, J.P.K

on wealth and poverty in

Psalms 107-150', HTS

Teologiese Studies/

a6805. https://doi.

Copyright:

(c) 2021. The Authors. Licensee: AOSIS. This work

licensed under the
The purpose of this article was to compare Jerome's and Augustine's sermons on the fifth book of the Psalms with regard to their views on the rich and the poor. After a brief consideration of the different audiences of Jerome and Augustine, we focused on their attitudes to wealth and poverty, and almsgiving and its relationship to eschatology. In both Jerome's and Augustine's commentaries we were confronted with problems regarding the nature of the collections, the composition of the audiences, and a lack of overlap between the two works, but it was possible to discern congruences and differences in their exegesis. In their preaching on poverty and riches, both homilists associated Judas with the devil and wealth. With regard to the identification of Christ and the poor, Jerome offers a somewhat uneasy exegesis in explaining that Christ stands at the right hand of the pauper, although the Lord himself is rich. Augustine mentioned the identification of Christ and the poor a few times in Enarrationes in Psalmos and framed the poverty of Christ within the body of the church, emphasising the common humanity of his congregation. In his sermons, mainly delivered to monks, Jerome advocated total renunciation. Augustine made more allowances for human frailty, advocating partial and gradual dispossession. The Songs of Ascent provided both our authors with the opportunity to consider the place of almsgiving in an eschatological context.

Contribution: We investigate the views of two prominent Latin fathers on wealth and poverty in their sermons on Psalms 109-150. The focus on wealth and poverty is evident. Judas is identified with the rich and Christ with the poor, placing Christ and riches against each other in an either/or position.

Keywords: Augustine; Jerome; wealth; poverty; almsgiving; Psalms.

\section{Introduction}

The purpose of this article is to compare Jerome's and Augustine's sermons on the fifth book of the Psalms ${ }^{1}$ with regard to their views on the rich and the poor. ${ }^{2}$ Within this book, Psalms 119-133 were known in the Jewish tradition as Songs of Ascent or of the Steps, also called in scholarly literature Pilgrim Songs. We have homilies from Jerome on 26 Psalms in the fifth book and some of them contain no information on poverty or wealth. Augustine for his part commented on Psalms 109-113 (the last one twice), 114-117, 118 (32 times), and 120-150 (in general, see Fiedrowicz, 1997). There is thus a considerable disparity between their treatment of the Psalms in their surviving sermons, only 25 Psalms being covered by both of them. ${ }^{3}$ In order to discuss our theme within the limited scope of an article, after a brief consideration of the audiences for whom Jerome and Augustine wrote, our primary focus will be on the following aspects: our authors' attitudes to (1) wealth and poverty, and (2) almsgiving and its relationship to eschatology.

\section{The audiences}

The Tractatus sive Homiliae in Psalmos ${ }^{4}$ written in 387 (according to Williams, 2006) are sermons which Jerome delivered to his fellow monks in Bethlehem (Pease 1907:107-131). The extent of 1.On the ancient division of the Psalms into five books see, for example, Gese (1974); Craigie (1983).

2.A number of books and articles devoted to the question of poverty in antiquity and early Christianity have recently been published. Some pertinent examples are Allen et al. (2009); Dunn et al. (2009); Holman (ed. 2008); Atkins and Osborne (eds. 2006); Finn (2006); Brown (2002).

3.These are Psalms 107 (very cursory in Augustine), 108, 109, 110 (short in Jerome), 111, 114, 115, 119, 127, 128, 131-133, 135-137, 139-143, 145-148. For ease of reference see the table provided in the Appendix Table 1-A1.

4.The text used is that of Morin (1958), (Corpus Christianorum. Series Latina, 78). We have also consulted Morin (1895). The English translation of the sermons that we reproduce is that of Ewald (1964).

Note: Special Collection: Historical Thought and Source Interpretation, sub-edited by Johann Cook (Stellenbosch University) 
Jerome's dependence on Origen in this work is not clear. Coppa (1993) in his re-evaluation of the question of authorship concludes that Origen should be regarded as the author of these sermons, and that while Jerome acted as an editor/ translator of the original, he adapted the text to his new context. According to Coppa, these adaptations were done so effectively that Augustine himself deduced that Jerome was the author. Jay (1989), arguing against the earlier work of Peri (1980:174-184) which claimed that the Tractatus were translations, pronounced that the sermons constituted 'un témoignage de la prédication personnelle de Jérôme à l'église de Bethléem.' The authors are also of the opinion that these sermons are more than translations, and that, even though Jerome cannot be regarded as the author of the work properly speaking, the contents certainly reflect Jerome's view of the material, especially after his editing of the original. ${ }^{5}$ In an old but valuable detailed study, Pease (1907:109) considered the style of these sermons, illustrating that it is distinctly different from that of Jerome's written works. Pease refers inter alia to its unusual swiftness, the fact that Jerome used short sentences, and his frequent use of apostrophe, rhetorical questions and repetition ${ }^{6}$. He ascribes this variation in style to the fact that the sermons were addressed to a completely different audience ${ }^{7}$ consisting of monks, whom Jerome called his spiritual brothers. ${ }^{8}$ He mentions a number of times that there are some unlearned ones among the listeners and that he has adapted his style for them. ${ }^{9}$ According to Ewald, 'his audience was now mixed Orientals and Latins with catechumens and novices' and she describes the style of the sermons as follows: 'Often unadorned, syntactically and grammatically inaccurate, with not a few errors in biblical citations, they clearly reflect their spontaneous character'. ${ }^{10}$ Scourfield (1997:536-539), in a note on Jerome's homily on the Rich Man and Lazarus, observes that a probable error in the text can be explained by the fact that Jerome's sermons were transcribed by his fellow-monks and not checked by him. We must, however, take into account that Jerome translated the original work of Origen and therefore, we can expect the style to differ from that of his other works.

With Augustine's Enarrationes in Psalmos (For the text of Enarrationes in Psalmos 107-150 [Clavis Patrum Latinorum

5.See further Jay (1989), 'Jérôme à Bethléem. Les Tractatus in psalmos', in Duval (1988:367-380); Rondeau (1985). On Jerome's debt to Origen in general see Vessey (1993:135-145).

6.Cf. also Ewald (1964:xix): 'Lacking in eloquence, they are not a work of the Hieronymean carefully polished style' and 'they are not finished products and appear in the natural and intimate form in which they were uttered - and recorded in shorthand by some monk without, perhaps, even the knowledge of the preacher'.

7.Pease (1907:109): 'Again, from the simplicity of his language and his explanations of Scripture, it is clear that he is not addressing a learned audience, but one composed in large measure of those to whom he refers as "simpliciores fratres".

8.Serm. 45 in Psalmum 132; Corpus Christianorum Series Latina (CCSL) 78:276, 12: Ergo quod dicit hic, fratres, non fratres dicit corpore, sed fratres spiritales. Cf. also Serm.34 in Psalms 107; CCSL 78:202, 31-32; Serm. 41 in Psalms 119; CCSL 78:259, 380-390.

9.For example, Serm. 39 in Psalmum 114; CCSL 78:236, 62-64: 'misericors Dominus et iustus: uerbi gratia, decem partes est misericors, et decem partes est iustus, et hoc propter simpliciores ita loquor'; Serm. 41 in Psalmum 119; CCSL 78:253, 207: 'dico simplicius propter simpliciores'.

10.Ewald (1964: xix). Cf. also xxviii: 'Not destined for publication, they were intended for simple monks; their tone, as we would expect under such circumstances, is almost colloquial'. With 'Orientals and Latins' Ewald refers to the audiences in Bethlehem and Rome respectively.
(CPL) 283] 1993) we are at even more of a disadvantage in determining the audience because the sermons were preached or written over a period of some 30 years, from the early 390s to the late 420s, and those that were actually delivered viva voce were given in a variety of North African towns and in different liturgical contexts. ${ }^{11}$ The 'audience' of Augustine's desk-sermons on the Psalms, ${ }^{12}$ many of which are very perfunctory and were presumably added afterwards to make the commentary complete, ${ }^{13}$ can only be guessed at, if Augustine indeed had a readership in mind at all. It is no surprise that from his long preaching and writing career, we have multiple sermons on the one Psalm: for example, no fewer than 32 of his pieces on Psalm 118 - for this group the preacher directed himself to the clergy in his monastery. ${ }^{14}$ Despite their composite character, the Enarrationes have been lauded for their originality and subsequent influence (e.g., by Fiedrowicz 1997:11; Rondeau 1985:174), an accolade that has not been accorded Jerome's sermons on the Psalms.

\section{Attitudes to wealth/poverty}

\section{The devil, Judas, and the rich}

The application of the curses in Psalm 108 to Judas is standard in Patristic exegesis of the Psalms. ${ }^{15}$ Jerome's twist, however, is to associate the devil and wealth with Judas. In fact, the devil occupies a prominent role in Jerome's homilies on the Psalms, and he, that is, the devil, is clearly on the side of the rich. The promise of worldly goods, which he uses to tempt the rich, is reminiscent of his temptation of Jesus in the wilderness (Mt 4:1-11). He is described as the one who gives gold and precious stones. ${ }^{16}$ The devil uses money as a temptation and distraction, for example, when a member of the congregation is sitting in church thinking about his investments. ${ }^{17}$ Sermo 43 in Psalmum 128, Jerome mentions how the wife of Potiphar, a very wealthy woman, tried to seduce Joseph, a poor young man, but that he realised it was the devil who was holding him. ${ }^{18}$ Judas is also associated with money and with the devil. Echoing Psalm 108:6 (Set a sinner over him, and let the devil stand at his right hand), Jerome relates that the devil stood at Judas' right hand ${ }^{19}$ and the name Iscariot means money and price. ${ }^{20}$ Judas is portrayed as an example of someone who did not use the money he

11.On the dating of the homilies to a 35 -year period see La Bonnardière (1977); Fiedrowicz (1997:23-24).

12.For a case-study of the problematic regarding distinguishing the desk-homily from the spoken homily, see Junod (1994).

13.See the prologue to En. in Psalmum 118; NBA 27/1, 1108: 'partim sermocinando in populis, partim dictando exposui'

14.See Rondeau (1982:169-170); cf. Allen and Neil (2011), on the nature of the audience.

15.See for example, Origen, Contra Celsum 2.11; John Chrysostom, Patrologia Graeca (PG) 55:261; Augustine, Contra litteras Petiliani 2.8-17; Theodoret, PG 80:1755A-1757B.

16.Serm. 34 in Psalmum 107; CCSL 78:208, 231-232.

17.Serm. 45 in Psalmum 132; CCSL 78:276, 19-20.

18.Serm. 43 in Psalmum 128; CCSL 78:270, 37-40.

19.Serm. 35 in Psalmum 108; CCSL 78, 220, 358-359.

20.Serm. 35 in Psalmum 108; CCSL 78, 213, 135-138. For the inconclusive exegesis of the appellation 'Iscariot' see Maccoby (1992:127-140). 
received from God wisely. ${ }^{21}$ The Jews are the sons of Judas, and according to Jerome, the widow mentioned in Psalm 108 refers to the synagogue since he could not find any evidence in the Bible that Judas had a wife or sons. ${ }^{22}$ Jerome extends the association of the rich with the devil to heretics, whom he compares to fat Egyptians, interested in nothing but their riches and scorning Christ as a pauper. ${ }^{23}$

Augustine's treatment of the connection between the devil and Judas also grows out of his exegesis of Psalm 108, but the emphasis is on Judas' greed rather than on the rich per se. Like Jerome, Augustine applies Psalm 108:6 specifically to Judas, but goes much further, quoting v. 10 (May his days be few. Let another man take over his office) to corroborate Judas' fate. Uninhibited by the fact that, as Jerome points out, there is no biblical evidence that Judas had a wife or sons, Augustine interprets vv. 11 and 12 (May his children become orphans, and his wife a widow. May his children be driven out, may they wander and beg) as a curse on the family of Judas, who, as the Psalm proceeds to describe, are set upon by creditors while strangers seize their property. The result is the fulfilment of v. 14: May those born to him perish, and his name be blotted out in one generation. Augustine goes even further still, arguing that Judas' greed and treachery rebounded not only on his wife and children, but also retrospectively on his father and mother: 'Let the iniquity of his fathers be remembered before the Lord, and his mother's sins not be effaced.' At the end of the Psalm, Augustine attempts to reconcile v. 6 (Let the devil stand at his right hand) with v. 31 (For he [sc. the Lord] has taken his stand at the poor person's right hand) by explaining that the Lord himself will be riches to the poor and will enable them to endure their poverty and weakness. In other words, there is no notion that the pauper will ever be anything but poor.

\section{Christ and the poor}

Also standard in Patristic homiletic material is the association of Christ with the poor. Jerome portrays Christ as showing his solidarity with the poor by becoming poor and a beggar himself; he is a pauper with us and that serves as a consolation to the poor. Just as the devil stands at the right hand of Judas, so the Lord stands at the right hand of the pauper, although Christ is himself rich. ${ }^{24}$ The question could be asked why Christ is negatively disposed to wealth, if he himself is rich, but it is not asked here. ${ }^{25}$ It could certainly be asked why one should not be striving to become rich, if the Lord himself is rich - a question raised by proponents of a prosperity

21.Serm. 35 in Psalmum 108; CCSL 78, 214, 177-183.

22.Serm. 35 in Psalmum 108; CCSL 78, 212, 163.

23.Serm. 54 in Psalmum 143; CCSL 78, 320, 228-230.

24.Serm. 35 in Psalmum 108; CCSL 78, 216, 223-227: 'Qui cum esset diues, propter nos pauper factus est' (2 Cor. 8:9). 'Dominus inopem se dicit et mendicum: et quis in diuitiis suis gloriatur? Habetis consolationem, pauperes: et Dominus uobiscum pauper est'.

25.Cf. also Serm. 46 in Psalmum 133; CCSL 78, 284, for a comparison of Christ with a very wealthy estate owner: 'Dicamus esse aliquem dominum ditissimum: iste habet familiam, habet et seruos qui sibi ministrant ... Dominus noster lesus Xpistus habet et ipse multam familiam ...' In Serm. 34 in Psalmum 107; CCSL 78, 204, 109-112, et ipse multam familiam ...' In Serm. 34 in Psalmum 107; CCSL 78, 204, 109-112,
Christ is also said to have many riches, but there Jerome seems to refer to the Gentiles who came to him. theology. It is, however, clear that, generally, Jerome places Christ and riches against one another in an either/or position. Where a positive attitude to wealth is mentioned, it is interpreted in a spiritual sense, where riches do not refer to the riches of the world, but to knowledge and preaching the Word. ${ }^{26}$ Poverty is likewise spiritualised, for example, where it refers to the punishment of the Jews for crucifying the Lord: they have been dispersed throughout the world and become beggars of spiritual riches. The Jews' condition is described emphatically by the fact that they 'do not have' ('non habent'): “"Begging" here refers to spiritual riches, for they have no prophets, they have no law, no priests, no sacrifice; they have become beggars in the true sense'. ${ }^{27}$ Earlier in the same homily Jerome says that Christians are 'Iudaei spiritales' but took their name from Judas, son of Jacob, while the Jews are the sons of Judas, the betrayer. ${ }^{28}$ There is thus a stark contrast between the spiritual poverty of the Jews and the spiritual wealth of the Christians, here called 'spiritual Jews'. ${ }^{29}$

Apart from the positive association of Christ and the poor, Jerome also refers to Paul in Sermo 57 in Psalmum 147, where he is explicitly called 'pauper' ${ }^{\prime 30}$ and in Sermo 46 in Psalmum 133, Jacob is called 'nudus', which can here also be translated as 'poor'. ${ }^{31}$ In the previous homily, Jesus himself is also described by the word 'nudus' as he hung naked on the cross. $^{32}$ By alternating between the physical and spiritual interpretations, on the one hand, Jerome can associate the Jews with physical wealth and spiritual poverty, and on the other hand, regard Christians who live in physical poverty as spiritually rich because they have Christ. In Sermo 54 in Psalmum 143 Jerome directly contrasts the riches of the devil with the poverty of Christ. The monks are therefore asked to sell everything and give it to the poor. The devil's promise, however, leads to death, while Christ's promise leads to salvation. ${ }^{33}$

Within the range of our Psalms in Augustine's Enarrationes in Psalmos there are but few references to Christ and the poor. This stands in contrast to his Sermones ad populum, where Matthew 25:31-46 is foundational in identifying Christ with the poor (See further Allen \& Morgan, 2009; Ramsey 1982: 226-259). In Sermo 19 in Psalmum 108, Christ is identified with

26.Serm. 38 in Psalmum 111; CCSL 78, 232, 40-47. Cf. also Serm. in Psalmum 111 CCSL 78, 233.77-234.90

27.Serm. 35 in Psalmum 108; CCSL 78, 214, 171-176: 'Ita igitur et isti, quoniam crucifixerunt Deum et Dominum suum, nutantes transferuntur (cf. Ps 108:10). Non enim sunt in suis locis, sed in toto orbe diuisi sunt. Mendicitatem hic dicit diuitiarum spiritalium. Non enim habent prophetas, non habent legem, non habent spiritalium. Non enim habent prophetas, non habent legem,
sacerdotium, non habent sacrificium, sed uere mendici facti sunt'.

28.The relationship between Judas and the Jews is found also in Augustine, although not in the Enarrationes. See, for example, Sermones 46.23, 152.10, and 214.3.

29.Serm. 35 in Psalmum 108; CCSL 78, 213, 124-127.

30.Serm. 57 in Psalmum 147; CCSL 78, 339, 103-105.

31.Serm. 46 in Psalmum 133; CCSL 78, 292, 267-268.

32.Serm. 45 in Psalmum 132; CCSL 78, 278, 79.

33.Serm. 54 in Psalmum 143; CCSL 78, 319-320, 196-201: 'Diabolus quid dicit? 'Haec omnia mea sunt: si procidens adoraueris me, dabo tibi ea.' Xpistus quid dicit ad suos? 'Qui non uendiderit omnia sua quae habet et dederit pauperibus, non potest esse meus discipulus.' Ille regna et diuitias pollicetur, ut occidat: hic paupertatem pollicetur, ut saluet' 
the poor as part of the concept of synkatabasis; ${ }^{34}$ he is 'inops et mendicus', persecuted by Paul. A second outright identification is found in Sermo 13 in Psalmum 147, 'Give to your needy brother. Who is this brother? Christ' ${ }^{35}$ Elsewhere Augustine argues that when one obeys Christ's command to serve another person, it is not the human being one is serving, but Christ himself. ${ }^{36}$ Here the poverty of Christ is framed within the body of the church, where everyone can help everyone else, a theme dear to Augustine's heart, particularly, as we shall see, with reference to almsgiving. In Sermo 12 in Psalmum 125, he outlines how those who can walk should assist those who cannot, those who can see should assist the blind, and so on. ${ }^{37}$ Augustine's identification of Christ with the poor thus goes further than the outright equivalence found in Jerome's commentary on the Psalms, in that it emphasises the common humanity of the congregation, consequently blurring the distinction between rich and poor while encouraging solidarity in his community (See further Allen \& Morgan 2009:127-164).

\section{Voluntary poverty}

Jerome refers to the voluntary poverty of the spiritual brothers (monks) who have no use for their own possessions and mentions Acts 4:32 pertaining to the sharing of all their possessions. ${ }^{38}$ As in Sermo 34 in Psalmum 107, in Sermo 54 in Psalmum 143 Jerome refers to the Lord who looks after the birds of the air. The monks, just as the birds, do not have granaries and they rely on the Lord of granaries, on Christ himself. ${ }^{39}$ The repetition of the phrase 'non habent' reminds us of its similar use in Sermo 35 in Psalmum 108. In that case, as noted above, Jerome interprets the lack of possessions in Judas' family as spiritual poverty. Here we have the same phrase, used four times, but now it points to the monks' physical poverty, which is viewed positively as it refers to their dependence on the Lord. Other than in the previous passage, the positive 'habent' is also used twice to indicate what they do have: '.. they do not have storehouses or depositories, but the Lord of granaries; they do not have the wealth of the devil, but they have the poverty of Christ.' The syntactical parallelism in 'Non habent divitias diaboli, sed habent paupertatem Xpristi" is striking and provides a typical example of Jerome's switching between the literal and spiritual exegesis that is characteristic of Jerome and also other Patristic authors' presentation of the wealth versus poverty discourse. In another sermon, using an image from the Jewish priesthood borrowed from Origen, ${ }^{40}$ Jerome envisages a 15-step journey to God, who stands on the last 34.NBA 27/2, 928-930. Cf. Serm. in Psalmum 30(2), 5 ; NBA 25, 492 . 35.NBA 28/2: "Da egenti fratri. Cui fratri? Christo". Trans. Boulding, WSA III/20, 454. 36.Serm. in Psalmum 124, 7; NBA 28/1, 98.

37.NBA 28/1, 130.

38.Serm. 45 in Psalmum 132; CCSL 78, 276, 26-30.

39.Serm. 54 in Psalmum 143; CCSL 78, 319, 190-196: 'Aues istae specialiter monachi sunt: non habent cellaria, non habent apothecas, sed habent apothecarum et cellariorum dominum ipsum Xpistum. Non habent horrea, sed horreorum dominum. Non habent diuitias diaboli, sed habent paupertatem Xpristi'. (our emphasis.)

40.See Libri X in Canticum canticorum (CPG 1433); Baehrens (1925). step. ${ }^{41}$ The second step in this journey, says Jerome, is total renunciation, a process in which the monks have left everything - parents, siblings, wives, children, native lands, homes, and so on; yet on coming to the monastery they fight over something so trivial as a reed pen. ${ }^{42}$

It has been argued recently that whereas Augustine's demand for poverty among his monks was uncompromising, he had gentler and more moderate demands for his congregations, lest the status quo be impaired. ${ }^{43}$ While his monks are not mentioned in the sermons under consideration here, ${ }^{44}$ that more moderate demands were laid on his congregations is borne out by references to voluntary and dispositional poverty in the Enarrationes in Psalmos 107-150. In Sermo 11 in Psalmum 122, Augustine addresses the problem of the wealthy Christian: 'A Christian has no business to be affluent but rather a duty to recognize that he is poor ${ }^{\prime}{ }^{45}$ Here it is a question of dispositional poverty and the fact that worldly wealth is not true wealth. In adducing the loci communes on wealth and poverty in Patristic literature of Zacchaeus (Lk 19:8) and the widow (Lk 21:1-4), Augustine points to the disposition of both donors, which indicates that there is parity in what they give. The preacher is keen to argue that Zacchaeus retained half of his fortune not because he wanted to keep something for himself but in order to pay his debts. There is no commendation of complete voluntary poverty here. ${ }^{46}$ Similarly in his commentary on Psalm 131:5-6, referring to Acts 4:32-34, Augustine remarks that those who want to make a place for the Lord should not rejoice in their private possessions but in what is common to all. At the same time, however, he makes provision for those who cannot renounce their possessions, by asking them not to love them. ${ }^{47}$ An imaginary or perhaps real objection to a total renunciation of one's possessions apparently commanded by Christ is addressed by Augustine in his commentary on Psalm 136:9: people say that it is ridiculous to donate one's possessions to the needy only to become needy oneself. ${ }^{48}$ The preacher replies: 'The devil who once took me prisoner has taken full possession of you, and he it is who is putting his carping questions through you.' ${ }^{49}$ The answer is to use wealth to lay a foundation for the future and so attain true life..$^{50}$ One way of doing this, Augustine suggests, is to set aside part of either one's annual income or daily profits for

41. On the theme of the ascent of the soul see further below. The idea of the 15 steps leading to perfection is also presented briefly in Commentariolus in Ps. 119; CCSL $72,235-236$

42.Serm. 41 in Psalmum 119; CCSL 78, 258, 382-390.

43.See Allen and Morgan (2009: 146-150). Cf. Finn (2006:91), on Augustine's praise of self-dispossession on entry into a monastic community.

44.The classic sermons on the voluntary poverty of Augustine's monks are 355 and 356. See further Allen \& Morgan (2009:146-147).

45.NBA 28/1, 56: 'At vero Christianus homo non debet abundare, sed pauperem se debet cognoscere.' Trans. Boulding; WSA II/20, 40.

46.En. in Psalmum 125, 11; NBA 28/1, 128.

47.En. in Psalmum 131, 5-6; NBA 28/1, 276-278.

48.En. in Psalmum 136, 9; NBA 28/1, 410.

49.NBA 28/1, 412; trans. Boulding, WSA III/20, 232.

50.NBA 28/1, 426 
poor relief, ${ }^{51}$ rather than divesting oneself completely of wealth (See further Allen 2011; Bruck 1956).

\section{Almsgiving and eschatology}

Since Psalms 119-133 were commonly known as Songs of Ascent or of the Steps, it is germane to our purpose to consider the eschatological focus of our two authors regarding their discourse on almsgiving, particularly in their exegesis of these Songs. ${ }^{52}$ While Jerome's surviving sermons deal with only six of the Songs, we have a complete, if composite, set from Augustine. ${ }^{53}$ Unlike John Chrysostom, who explains in his commentary on these Psalms that they recount the return of the Israelites from Babylon and refer to their captivity there, ${ }^{54}$ Jerome and Augustine content themselves with a spiritualising exegesis, replete, however, with references to pilgrimage. In his commentary on Psalm 133, Jerome interprets the expression 'to lift the hands' ('extollere manus' or 'levare manus') as giving alms to the poor. The difference between the almsgiving of Christians and others lies in the fact that the former raise their hands towards the sanctuary ('in sancta'), which means that they acknowledge Christ. ${ }^{55}$ Jerome's argumentation in this long homily on a very short Psalm (only three verses) rests to a large extent on his interpretation of this expression. Augustine does not interpret this expression in the same way and makes no mention of almsgiving in his sermon on Psalm 133.

A point Jerome makes in a rhetorical question is that many holy people have engaged in almsgiving and have still fallen from sanctity. He does not give examples nor does he elaborate on the reasons for this lapse, but it may perhaps refer to heretics who had strayed from the catholic faith. This certainly indicates that almsgiving as such provides no guarantee: it cannot buy salvation. Or is it possible that it could, but only under certain conditions? The attitude or disposition of the giver and the motive for giving are discussed at great length. ${ }^{56}$ Some Christians give alms in order to be seen and praised by the people, but in this case, it only appears to be real almsgiving; in fact, it is a wrong before God. ${ }^{57}$ The alms should be given 'not as from our own substance, but as from Christ's $\mathrm{s}^{\prime 58}$ and (with reference to 1 Cor

51.En. in Psalmum 146, 17 ; NBA 28/2. 794.

52.On the ideas behind such discourse see Garrison (1993).

53.Jerome mentions the Songs explicitly in his commentary on Psalms 119 (the 15 steps) and 133; Augustine regularly refers to the corpus of the Songs at the beginning of each exposition, with the exception of those on Pslams 127, 128, 130 132 , and 133 . These five exceptions are probably to be attributed to the composite 132 , and 133 . These five exceptions are probably to be attributed to the composite
nature of his commentary. For Augustine's notion of 'ascensio' in these Psalms see Fiedrowicz (1997:226-229)

54.Psalms 119 (120); PG 55, 338-339.

55.Serm. 46 in Psalmum 133; CCSL 78, 287, 135-142. On pagan almsgiving see Hands (1968); Parkin (2001); Parkin (2006). On Jewish almsgiving in this period see Neil (2010:231-244).

56.Serm. 46 in Psalmum 133; CCSL 78, 288-289, 147-177.

57.Serm. 46 in Psalmum 133; CCSL 78, 288, 150-161. Cf. Serm. 51 in Psalmum 140; CCSL 78, 307, 164-170, where almsgiving intended to be seen by others is CCSL 78, 307, 164-170, where almsgiving intended to be seen by others is apply in the case of fasting, praying, and wearing haircloth (176-181).

58.Serm. 46 in Psalmum 133; CCSL 78, 288, 159-161: 'Quando ergo damus, non demus quasi de nostro, sed de Xpisti'.
10.31) whatever we do must be done for the sake of Christ. ${ }^{59}$ If we give material things to the poor with honest motives (i.e. as if to Christ), the poor give more than they receive: we give bread and receive in return the kingdom of heaven. ${ }^{60}$ The idea that the donor will receive a reward and a blessing for virtuous deeds is mentioned again and again with an eschatological focus, namely the heavenly Jerusalem. ${ }^{61}$ Jerome mentions that Psalm 133 is the 15th and last Psalm in the Songs of the Steps. These 15 steps lead to the eschatological heavenly Jerusalem and in Psalm 133, which represents the final step, almsgiving plays a central role. According to this statement, it seems as if, for Jerome, almsgiving, which he associates with humility, is the ultimate step, in the words of Ewald, more sublime than the preceding steps. ${ }^{62}$

Gratitude, says Jerome, is due by the recipient of alms who has received something, and also by the donor, who has received everything he has from God, and therefore has the means to give to another. But there is also another reason to be thankful, namely that the recipient of the alms is giving the donor an opportunity to wash away sins. ${ }^{63}$ Jerome states that the giver has indeed more reason to be thankful and should thank Christ more than his brother thanks him. Why? Because the poor are doing us a huge favour (Grande nobis beneficium praestant pauperes) and that pertains to the washing away of our sins. A further, eschatological motivation for almsgiving is thus presented here, namely the washing away of sins, which is described as a service rendered by the poor. Jerome here quotes from Sirach (Ec 3.33) which says that almsgiving extinguishes sins, just as water extinguishes fire, ${ }^{64}$ pointing out that in this way almsgiving has the same function as baptism. It is worth noting that in this passage Jerome refers to the recipient of alms in such a way that we can assume the recipient is also a brother and not just any poor person. ${ }^{65}$ The relationship between almsgiving and eschatology in Jerome is, however, difficult to tie down. ${ }^{66}$ Also difficult to assess is his general attitude to genuine caritative activities, a point brought out well in a recent study by Andrew Cain. ${ }^{67} \mathrm{~A}$ further 59.Serm. in Psalmum 133; CCSL 78, 288-289, 174-180.

60.Serm. 46 in Psalmum 133; CCSL 78, 288, 161-164. Cf. also Serm. 35 in Psalmum 108; CCSL 78, 216, 237-238: 'Cum hominibus pauper factus est, ut salutem nemo pauperum desperet' [where temporal poverty is linked to an eschatological expectation of salvation].

61.Serm. 46 in Psalmum 133; CCSL 78, 290, 210-216.

62.Serm. 46 in Psalmum 133; CCSL 78, 283, 7-8: 'Videte quomodo paulatim ascendit per gradus, et ad sublimiora pervenit'. Trans. Ewald 1964: 341: 'Notice how gradually he mounted step by step, alway ascending to something more sublime'. In Serm. 41 in Psalmum 119 Jerome calls fasting the first step, and true renunciation of the world, or detachment, the second: CCSL 78, 249, 109-250,113. No mention of the world, or detachment, the second: CCSL 78, 249, 109-250, 113 . No mention
is made of the intervening steps, partly because of the defective transmission of is made of the in
the sermons.

63.Serm. 46 in Psalmum 133; CCSL 78, 288-289, 193-197.

64. Regarding the question of almsgiving and the redemption of sin, Garrison (1993: 66), says the following: 'Origen, Cyprian and Chrysostom all cite Lk 11:41 as a proof-text to support the doctrine that almsgiving redeems sin. Even Augustine refers to this passage to justify his belief that almsgiving was redemptive'.

65.Serm. 46 in Psalmum 133; CCSL 78, 289, 196-200.

66.See O'Connell (1948); Schanzer (2009:87-103) especially 98: 'Jerome's eschatology has always been notoriously messy and difficult to pin down'

67.Cain (2009), especially 42 on Jerome's support by high-profile ascetic women and 198 on the criticism he attracted for his extreme attitude to asceticism. 
consideration is that, as with Augustine and other writers, we need to differentiate between the alms given by people during their own lifetime and those given by others on behalf of a dead person. A passage on almsgiving in Sermo 46 in Psalmum 133 seems to indicate that Jerome believed that somehow alms given by others might provide relief from hell (Discussed by Schanzer 2009:98-99), but the evidence is not conclusive. This consideration will lead us in due course to discuss Augustine's views on the eschatological value of almsgiving.

Outside the Songs of the Steps, we find other references to almsgiving and eschatology in Jerome's commentary on the fifth book of the Psalms. The question of whether the monks (the voluntary poor) should give alms is discussed in Sermo 38 in Psalmum 111. Commenting on verse 5 (Well for the man who has mercy and lends), Jerome urges the just person to imitate the Lord's mercy and kindness. Again, he says that the Psalmist is not referring to gold, silver, and money. Indeed, the just have been in want to such an extent that they have received food from others. ${ }^{68}$ This raises the question whether the poor, who cannot give alms, can be considered just. Yes, says Jerome, for many wealthy almsgivers have fallen from sanctity, whereas the perfected ones have not given alms because they had none to give. To prove that almsgiving is broader than giving material items, the homilist quotes Peter's words in Acts 3:6 (Silver and gold I have none, but what I have I give you. In the name of the Lord Jesus, get up and walk). The lesson appears to be that while the just cannot give money, they can give alms through their miracles, or perhaps through sharing their riches, such as their knowledge or services. Jerome adds a caution in referring to Matthew 7:6 about casting pearls before swine: one should know what to give and to whom to give. His advocacy of discriminate giving seems to pertain not to material items but to preaching the word, and, consequently, it is not only the rich who can give: the poor can also give to the rich, even if it is only a question of goodwill in a client-patron relationship. Jerome refers to the widow who gave two coins (Lk 21:2-4).

Let us now consider Augustine on the topic of almsgiving and eschatology. ${ }^{69}$ In Enarratio in Psalmum 111, 8 he considers the grim plight of the sinner in the next world on seeing 'the one who freely dispersed his goods to the poor, with his horn raised up in glory, ${ }^{\prime 70}$ a clear indication that almsgiving expedites one's journey to heaven. These good works, Augustine advises, should be kept hidden, but they will help people to eternal life. ${ }^{71}$ Enarratio in Psalmum 121, one of the Songs of the Steps, contains much graphic information on how to ascend to heaven, called by Augustine the eternal Jerusalem, and it is unfortunate that we cannot compare it

68.It is not clear whether Jerome is referring to the early community of Christians described in Acts 5:34-35, or to his monastic community of voluntary poor, or whether this is simply a throw-away line.

69.In general, see Finn (2006:147-150), who confines himself to the Sermones ad populum, and Allen and Morgan (2009:130-146).

70.NBA 27/2, 1018: 'cornu eius exaltari in gloria, qui sparsit et dedit pauperibus.' Trans. Boulding, WSA III/19, 296.

71.En. in Psalmum 120, 10; NBA 27/2, 1446 with Jerome's lost homily on this Psalm. This eternal city, Augustine explains in the language of the Psalm, is in the process of being built, and it is a city of peace. It is also the seat of the judgement that the Lord and the saints will bring down on just and sinner alike. Augustine elaborates: 'What is the Jerusalem peace? It means that corporal works of mercy are joined with spiritual works of preaching, so that in both giving and receiving there may be peace'.

The apostle saw alms deeds as a matter of due payment and receipts (Phlp 4:15). ${ }^{72}$ The pilgrimage to the heavenly Jerusalem, also called the Lord's house, is effected not on foot but by affections or disposition, ${ }^{73}$ and the congregation are urged to check their progress along the way by questioning their compassion to the poor and needy. Augustine warns that while the rich person possesses gold, he does not yet possess eternal life, which he can, however, attain by giving to others less fortunate. ${ }^{74}$ For all his emphasis here on spiritual progress, Augustine does not enumerate the steps of ascent, as he does elsewhere (See Kamimura 2006; Neil 1999). In his exposition of Psalm 127, Augustine speaks of one's children's children as the fruit of good works performed on earth: 'You give alms; they are your children. Because of alms you receive eternal life; they are children of your children. ${ }^{75}$ It is passages like this that have led scholars to believe that Augustine's main concern lay with the salvation of the individual donor and not with the poor. ${ }^{76}$ A further problem is that, like Jerome's eschatology, Augustine's is nascent, contradictory, and difficult to pin down. For example, given Augustine's concept of predestination, we may reasonably wonder what motivation his congregation had for giving alms if they were uncertain what their fate was in the life hereafter (See further Allen \& Morgan 2009:134-136; Ntedika 1966).

\section{Concluding observations}

While in both Jerome's and Augustine's commentaries on the Psalms we are confronted with problems regarding the nature of the collections, the composition of the audiences, and a certain lack of overlap between the two works, it is possible to discern congruences and differences in their exegesis of Psalms 109-150. Jerome's audience seems to have been composed mostly of monks and sometimes of illiterate people, yet he does not spare them some uncompromising exegesis of Hebrew words and customs, such as the 15 steps of the Temple. Augustine's audiences over a 30-year period were mixed, some including his monks and others the various congregations in North African towns: one wonders how much they would have

72.En. in Psalmum 121, 9; NBA 28/1, 24: "Quae est pax lerusalem? Ut opera misericordiae corporalia iungantur operibus praedicationis spiritalibus, et fiat pax dando et accipiendo. Ait enim Apostolus, qui rationem dati et accepti dixit esse istas eleemosynas' [author's own translation].

73. Repeated, for example, in En. in Psalmum 123, 1; NBA 28/2, 60.

74.En. in Psalmum 121, 11; NBA 28/2, 28

75.En. in Psalmum 127, 16; NBA 28/1. 194: 'Facis eleemosynas, filii tui sunt: propter eleemosynas accipis vitam aeternam, filii filiorum tuorum sunt' [author's own translation].

76.See, for example, Chiappa (1975), discussed by Canning (1993). It is difficult to agree with Fitzgerald (1989:447), that Augustine 'does not turn the poor into a means of sanctification for the rich'. See further Allen and Morgan (2009:131-132). 
appreciated their preacher's linguistic asides as he commented on Greek words. In their preaching on poverty and riches both homilists associate Judas with the devil and wealth, as do other homilists in the Patristic era. The trope that the Jews are related to Judas appears in Jerome, but not here in Augustine. The devil is prominent in Jerome, where he is on the side of the rich, while in the Enarrationes the emphasis is on Judas' greed, rather than on the nexus between the devil and the rich. Augustine's exegesis of the fate of Judas and his family after his act of betrayal is much more fanciful than Jerome's and seems to be unique. With regard to the identification of Christ and the poor which is developed in Psalm 108, Jerome offers a somewhat uneasy exegesis in explaining that Christ stands at the right hand of the pauper, although the Lord himself is rich. This is perhaps the result of a stylistic constraint as the preacher tries to balance this statement against the devil's stand at the right hand of Judas. Although Augustine mentions the identification of Christ and the poor only a few times in Enarrationes in Psalmos 107-150, he goes further than Jerome in framing the poverty of Christ within the body of the church, emphasising the common humanity of his congregation, and encouraging solidarity in his community.

Let us now summarise the attitudes of our two authors with regard to voluntary poverty as they express themselves in their commentaries on the fifth book of the Psalter. Since Jerome's sermons are mainly, if not exclusively, delivered to monks, it is not surprising that he advocates total renunciation, which he describes as the second step in a 15step ascent. While in his other works Jerome's views on total renunciation, particularly by consecrated virgins, are extreme (as discussed by Finn 2006:249-257), we should not lose sight of a certain self-interest in his attitude to voluntary poverty, because, in Schanzer's (2009:102, Cf. Cain 2009:83) words, he 'was dependent himself on handouts and had a ready eye for a legacy'. Given the varieties of audiences or readerships that Augustine was catering for in the Enarrationes, it is equally unsurprising that he should make more allowances for human frailty than Jerome did, advocating partial and gradual dispossession. We know from Augustine's other writings, however, that he was strict in enjoining total renunciation on his monks. In both our authors there is a tendency to spiritualise poverty and stress the importance of the right disposition. The spiritualisation of poverty in the Enarrationes is particularly striking compared with Augustine's other works (as remarked in Allen \& Neil 2011).

The Songs of Ascent in the fifth book of Psalms provided both our authors with the opportunity to consider the place of almsgiving in an eschatological context. We have mentioned the 15 steps of ascent in Jerome, of which almsgiving is the final and most sublime. At one stage Jerome seems to suggest that alms given by others on behalf of a dead person could provide relief from hell. Augustine's ideas on post-mortem almsgiving do not appear in the
Enarrationes; in his other works they are secondary to the importance of prayer on behalf of the dead, and he makes it clear that if the dead person was not baptised and had not led a good life, then any such works of mercy on their behalf are useless (See Rebillard 2009). In Augustine, the ascent in Psalms 119-133 is presented as a journey to the heavenly Jerusalem, an undertaking that is expedited by almsgiving. Whereas in his other works like De vera religione, De quantitate animae, and De sermone domini in monte, Augustine speaks of a seven-stage ascent, in Enarrationes the stages are not spelled out. ${ }^{77}$ The arithmetical difficulty of applying a seven-step ascent to the 15 Songs must have deterred him from this exercise. Here Jerome was more successful in his recourse to Origen's symbolism of the Temple priesthood, although, like Origen, he did not spell out the nature of all 15 steps.

\section{Acknowledgements}

We are grateful to our colleagues in the Department of Ancient and Modern Languages and Cultures at the University of Pretoria and to Dr Alan Moss CFC of Australian Catholic University for advice on the subject of the Old Testament.

\section{Competing interests}

The authors declare that they have no financial or personal relationships that may have inappropriately influenced them in writing this article.

\section{Authors' contributions}

P.A. was mainly responsible for the work on Augustine and the final review and editing, while J.P.K.K. was mainly responsible for the work on Jerome and the project administration. The comparison was a joint effort.

\section{Ethical considerations}

This article followed all ethical standards for research without direct contact with human or animal subjects.

\section{Funding information}

This research received no specific grant from any funding agency in the public, commercial or not-for-profit sectors.

\section{Data availability}

Data sharing is not applicable to this article as no new data were created or analysed in this study.

\section{Disclaimer}

The views and opinions expressed in this article are those of the authors and do not necessarily reflect the official policy or position of any affiliated agency of the authors.

77.See Kamimura (2006:301-305), on the fact that in De sermone domini in monte the eight maxims of the Sermon on the Mount are reduced to seven, the eighth being considered by Augustine a recapitulation of the first. 


\section{References}

Allen, P., 2011, 'Challenges in approaching patristic texts from the perspective of contemporary catholic social teaching', in J. Leemans, B.J. Matz \& J. Verstraeten (eds.), Reading patristic texts on social ethics: Issues and challenges for twentyfirst-century Christian social thought, pp. 28-40, Catholic University of America Press, Washington, DC

Allen, P. \& Morgan, E., 2009, 'Augustine on poverty', in P. Allen, B. Neil \& W. Mayer (eds.), Preaching poverty in late antiquity: Perceptions and realities, pp. 127-164, Evangelische Verlagsanstalt, Leipzig.

Allen, P. \& Neil, B., 2011, 'Discourses on the poor in the Psalms: Augustine's enarrationes in Psalmos', in C. Harrison, A. Casiday \& A. Andreopoulos (eds.), Meditations of the heart essays in honour of Andrew Louth, pp. 181-204, Brepols, Turnhout.

Allen, P., Neil, B. \& Mayer, W., 2009, Preaching poverty in late antiquity: Perceptions and realities, Evangelische Verlagsanstalt, Leipzig.

Atkins, E.M. \& Osborne, R. (eds.), 2006, Poverty in the roman world, Cambridge University Press, Cambridge.

Baehrens, W.A., 1925, Origenes werke, J.C. Hinrichs'sche Buchhandlung, Leipzig.

Brown, P., 2002, Poverty and leadership in the later Roman empire, University Press of New England, Hanover.

Bruck, E.F., 1956, Kirchenväter und soziales Erbrecht: Wanderungen religiöser Ideen durch die Rechte der östlichen und westlichen Welt, Springer, Berlin.

Cain, A., 2009, The letters of Jerome: Asceticism, biblical exegesis, and the construction of Christian authority in late antiquity, Oxford University Press, Oxford.

Canning, R.F., 1993, The unity of love for God and neighbour in St. Augustine, Augustinian Historical Institute, Heverlee-Leuven.

Chiappa, P.V., 1975, Il tema della povertà nella predicazione di sant'Agostino, Giuffre, Milano.

Coppa, G., 1993, Origene - Gerolamo, Settantaquattro omelie su libro dei Salmi, Introduzione, traduzione e note, Letture cristiane del primo millenio, Edizion Paoline, Milan.

Craigie, P.C., 1983, Word biblical commentary: Psalms 1-50, Word Books, Waco, TX.

Dunn, G.D., Luckensmeyer, D. \& Cross, L., 2009, Prayer and spirituality in the early church, St. Pauls Publications, Strathfield.

Duval, Y.-M., 1988, Jérôme entre l'occident et l'orient: XVle centenaire du départ de saint Jérôme de Rome et de son installation à Bethléem: Actes du colloque de Chantilly, Septembre 1986, Etudes Augustiniennes, Paris.

Enarrationes in Psalmos 107-150 (CPL 283), we have used Nuova Biblioteca Agostiniana (=NBA), Parte III: Discorsi, vol. 27/1, 28/1, 28/2 2nd ed., (Rome, 1993, transl. M. Boulding, 2003-2004, Expositions of the Psalms (Enarrationes in Psalmos), The works of Saint Augustine (=WSA), A translation for the 21st century, vols $1 \mathrm{II} / 19$ and III/20, Hyde Park, NY.

Ewald, M.L., 1964, The homilies of Saint Jerome, Catholic University of America Press, Washington, DC.

Fiedrowicz, M., 1997, Psalmus vox totius Christi: Studien zu Augustins 'Enarrationes in Psalmos', Herder, Freiburg im Breisgau.

Finn, R.D., 2006, Almsgiving in the later Roman Empire: Christian promotion and practice, Oxford University Press, Oxford.

Fitzgerald, A.D., 1989, 'Almsgiving in the works of St. Augustine', in A. Zumkeller (ed.), Signum pietatis: Festgabe für Cornelius Petrus Mayer zum 60. Geburtstag, pp. 445-459, Augustinus-Verlag, Würzburg.

Garrison, R., 1993, 'Redemptive almsgiving in early Christianity', Journal for the Study of the New Testament 77.

Gese, H., 1974, Vom Sinai zum Zion: Alttestamentliche Beiträge zur biblischen Theologie, Kaiser, München

Hands, A.R., 1968, Charities and social aid in Greece and Rome, Cornell University Press, Ithaca, NY.
Holman, S.R., (ed.), 2008, Wealth and poverty in early church and society, Baker Academic, Grand Rapids, MI.

Jay, P., 1989, 'Combien Jérôme a-t-il traduit d'homélies d'Origène?', Studia Patristica 23, 133-137.

Junod, E., 1994 'Wodurch unterscheiden sich die Homilien des Origenes von seinen Kommentaren?', in E. Mühlenberg \& J. Van Oort (eds.), Predigt in der alten Kirche, pp. 50-81, Kok Pharos, Kampen.

Kamimura, N., 2006, 'Friendship and ascent of the soul in Augustine', in W. Mayer, P. Allen \& L. Cross (eds.), Prayer and spirituality in the early church, vol. 4, The spiritual life, pp. 295-310, St. Pauls Publications, Strathfield.

La Bonnardière, A.-M., 1977, 'La prédication d'Augustin sur les Psaumes à Hippone', Annuaire de l'École pratique des hautes études, Ve section: Sciences religieuses $86,8$.

Maccoby, H., 1992, Judas Iscariot and the Myth of Jewish Evil, Free Press, New York, NY.

Morin, G., 1895, Sancti Hieronymi presbyteri qui deperditi hactenus putabantur commentarioli in Psalmos, Apud Editorem, Maredsous.

Morin, G., 1958, S. Hieronymi presbyteri opera: Pars ii: Opera homiletica (Corpus Christianorum. Series Latina, 78), Brepols, Turnhout.

Neil, B., 1999, 'Neo-platonic influence on Augustine's conception of the ascent of the soul in De quantitate animae', in P. Allen, W. Mayer \& L. Cross (eds.), Prayer and spirituality in the early church, vol. 2, pp. 197-215, Centre for Early Christian Studies, Everton Park.

Neil, B., 2010, 'Models of gift giving in the preaching of Leo the Great', Journal of Early Christian Studies 18(2), 225-259. https://doi.org/10.1353/earl.0.0322

Ntedika, J., 1966, L'évolution de la doctrine du purgatoire chez saint Augustin, Études Augustiniennes, Paris.

O'Connell, J.P., 1948, The eschatology of Saint Jerome, Saint Mary of the Lake Seminary, Mundelein.

Parkin, A.R., 2001, 'Poverty in the early Roman Empire: Ancient and modern conceptions and constructs', PhD Dissertation, University of Cambridge.

Parkin, A.R., 2006, “'You do him no service”: An exploration of pagan almsgiving', in E.M. Atkins \& R. Osborne (eds.), Poverty in the Roman world, pp. 60-82, Cambridge University Press, Cambridge.

Pease, A.S., 1907, 'Notes on St. Jerome's tractates on the Psalms', Journal of Biblical Literature 26(2), 107-131. https://doi.org/10.2307/3260061

Peri, V., 1980, Omelie origeniane sui salmi: Contributo all'identificazione del testo latino, Biblioteca apostolica vaticana, Città del Vaticano.

Ramsey, B., 1982, 'Almsgiving in the latin church: The late fourth and early fifth centuries', Theological Studies 43, 226-259. https://doi.org/10.1177/0040563 98204300202

Rebillard, É., 2009, The care of the dead in late antiquity, Cornell University Press, Ithaca, NY.

Rondeau, M.-J., 1982, Les travaux des Pères grecs et latins sur le Psautier: Recherches et bilan, Pontificium Institutum Studiorum Orientalium, Roma.

Rondeau, M.-J., 1985, Les commentaires patristiques du Psautier: III - Ve siecles, Pont, Roma.

Schanzer, D., 2009, 'Jerome, Tobit, Alms, and the Vita Aeterna', in A. Cain \& J. Löss (eds.), Jerome of Stridon: His life, writings and legacy, pp. 87-103, Ashgate, Farnham.

Scourfield, J.H.D., 1997, 'A note on Jerome's Homily on the rich man and Lazarus', The Journal of Theological Studies 48(2), 536-539. https://doi.org/10.1093/ jts/48.2.536

Vessey, M., 1993, 'Jerome's origen: The making of a Christian literary Persona', Studia Patristica 28, 135-145.

Williams, M.H., 2006, The monk and the book: Jerome and the making of Christian scholarship, University of Chicago Press, Chicago, IL. 


\section{Appendix 1}

TABLE 1-A1: Equivalences in Jerome's and Augustine's sermons on Psalms 107-150.

\begin{tabular}{|c|c|}
\hline Jerome & Augustine \\
\hline 107 & 107 \\
\hline 108 & 108 \\
\hline 109 & 109 \\
\hline 110 & 110 \\
\hline 111 & 111 \\
\hline- & 112 \\
\hline- & 113 \\
\hline 114 & 114 \\
\hline 115 & 115 \\
\hline- & 116 \\
\hline- & 117 \\
\hline- & 118 (32 sermons) \\
\hline 119 & 119 \\
\hline- & 120 \\
\hline- & 121 \\
\hline- & 122 \\
\hline- & 123 \\
\hline- & 124 \\
\hline- & 125 \\
\hline- & 126 \\
\hline 127 & 127 \\
\hline 128 & 128 \\
\hline- & 129 \\
\hline - & 130 \\
\hline 131 & 131 \\
\hline 132 & 132 \\
\hline 133 & 133 \\
\hline - & 134 \\
\hline 135 & 135 \\
\hline 136 & 136 \\
\hline 137 & 137 \\
\hline - & 138 \\
\hline 139 & 139 \\
\hline 140 & 140 \\
\hline 141 & 141 \\
\hline 142 & 142 \\
\hline 143 & 143 \\
\hline- & 144 \\
\hline 145 & 145 \\
\hline 146 & 146 \\
\hline 147 & 147 \\
\hline 148 & 148 \\
\hline 149 & 149 \\
\hline- & 150 \\
\hline
\end{tabular}

